Brit. F. vener. Dis. (1969), 45, 232.

\title{
KANAMYCIN SULPHATE IN THE MANAGEMENT OF GONORRHOEA FAILING TO RESPOND TO PENICILLIN*
}

\author{
BY \\ LAWRENCE FARRELL \\ From the Venereal Diseases Department, the Middlesex Hospital, London, W.1.
}

With an increasing number of strains of gonococci exhibiting partial resistance to penicillin, kanamycin, usually effective in routine therapy of gonorrhoea (Wilkinson, Race, and Curtis, 1967; Hooton and Nicol, 1967), was assessed for its efficacy in the management of cases in which there had already been failure of treatment with penicillin. 100 such cases were investigated, of which 83 were found to be due to infection with strains partially resistant to penicillin in vitro.

\section{Material and Methods}

37 female patients and 63 male patients with gonorrhoea were studied. Of the males 25 were homosexual, and twelve of these were suffering from gonococcal proctitis. Table I shows the sites of infection amongst the 100 patients. Infections in females were regarded as complicated if there was salpingitis or proctitis.

During the trial period patients were chosen who had gonorrhoea which had failed to respond to a single intramuscular injection of 800,000 units of fortified procaine penicillin. Cases of genital or rectal gonorrhoea were included in the trial irrespective of race, age, sex, or whether it was known initially that the strain was sensitive or insensitive to penicillin in vitro. Extreme care was taken to establish as accurately as possible that the case did in fact represent a failure of penicillin therapy and was not a re-infection. Thus, highly promiscuous patients who had a long history of recurrent attacks of gonorrhoea were not included.

^Received for publication, January 24, 1969.
Pregnant women or patients with a history of hearing defects or kidney disease were also excluded from the trial.

The organism was presumed to be partially resistant to penicillin if gonococci were detected on examination at the visit following the routine penicillin treatment, usually 3 or 4 days later. The gonococci were detected by microscopy of a Gram-stained specimen taken from the site of infection, and their presence was confirmed by culture of these specimens. Final identification was obtained by means of colonial appearances, the oxidase reaction, and fermentation tests.

In the cases selected, $2 \mathrm{~g}$. kanamycin sulphate were injected intramuscularly, and assessment took place again in 3 days' time. If gonococci were identified at the time of this re-assessment, all attempts having been made to exclude the possibility of re-infection, the strain was recorded as "presumed resistant to kanamycin".

The planned schedule for the follow-up of female cases was to take smears and cultures after 3 days, then at weekly intervals for 1 month, and then monthly for 2 months. In male cases the schedule for follow-up was examination and two-glass urine test 3 days after treatment, examination of the prostatic secretion after 1 month, urethroscopy after 5 weeks, and a final blood test after 3 months. It was difficult to apply this schedule because so many of the patients defaulted.

\section{Bacteriological Methods}

All bacteriological specimens were incubated for $48 \mathrm{hrs}$ after inoculation on chocolate agar. Sensitivities to

TABLE I

DISTRIBUTION OF INFECTIONS AND SENSITIVITIES IN VITRO

\begin{tabular}{|c|c|c|c|c|c|}
\hline \multirow[b]{2}{*}{ Sex } & \multirow{3}{*}{$\begin{array}{l}\text { Site of Infection } \\
\begin{array}{l}\text { Urethritis } \\
\text { Proctitis }\end{array}\end{array}$} & \multirow{3}{*}{$\begin{array}{c}\begin{array}{c}\text { No. of } \\
\text { Cases }\end{array} \\
13 \\
12\end{array}$} & \multicolumn{3}{|c|}{ Sensitivities in vitro } \\
\hline & & & $\begin{array}{c}\text { Penicillin Resistant } \\
(0.5 \text { U.) }\end{array}$ & $\begin{array}{c}\text { Penicillin Sensitive } \\
(0.03 \text { U.) }\end{array}$ & $\begin{array}{c}\text { Kanamycin Resistant } \\
(30 \mu \mathrm{g} .)\end{array}$ \\
\hline Male Homosexual & & & $\begin{array}{r}10 \\
8\end{array}$ & $\begin{array}{l}3 \\
1\end{array}$ & $\begin{array}{l}\text { Nil } \\
\text { Nil }\end{array}$ \\
\hline „ Heterosexual & Urethritis & 38 & 32 & 6 & Nil \\
\hline Female & $\begin{array}{l}\text { Cervicitis } \\
\text { Urethritis } \\
\text { Cervicitis } \\
+ \\
\text { Urethritis } \\
\text { Complicated }\end{array}$ & $\begin{array}{r}5 \\
2 \\
25 \\
5\end{array}$ & $\begin{array}{r}5 \\
2 \\
22 \\
4\end{array}$ & $\begin{array}{l}- \\
- \\
1\end{array}$ & $\begin{array}{l}\text { Nil } \\
\text { Nil } \\
\text { Nil } \\
\text { Nil }\end{array}$ \\
\hline
\end{tabular}


kanamycin and penicillin were determined by the disc method, using discs of $30 \mu \mathrm{g}$. kanamycin and of 0.03 and $0.5 \mathrm{U}$. of penicillin. Of the 100 gonococcal isolates studied, 83 were partially resistant in vitro to penicillin and eleven were sensitive. In the remaining six instances cultural confirmation failed, but reexamination of the original slides showed typical Gram-negative intracellular diplococci. None of the strains was resistant to kanamycin in vitro.

\section{Results}

Of the 100 patients treated, thirteen defaulted immediately after treatment, all of them males with urethritis, leaving 87 patients in whom results could be assessed. Failure of treatment occurred in two cases in men, both homosexuals with urethritis, and in two cases in women, one of cervical and rectal infection, the other of cervical and urethral infection.

The overall success rate was therefore 83 of 87 cases or 95.4 per cent. These results of treatment and the extent of follow-up in the successful cases are summarized in Tables II and III.

\section{Side-Effects}

There were six reported possible adverse reactions to the kanamycin injection. Many patients complained that it was painful but only two complained of undue discomfort. One of these complained of soreness and stiffness of the gluteal muscles for several days after the injection, and one patient complained of a painful injection site for a few hours. In each case the pain was not incapacitating. In one case a papular rash appeared 6 hours after the kanamycin and was observed to be present 3 days later. There was no evidence of syphilis. One patient complained of fever for 12 hours after the injection, but no more specific information was available.
In another case, severe oedema of the face was observed for several days after the kanamycin; the oedema appeared a few hours after the injection. There was one vaso-vagal attack. In all these cases intramuscular penicillin had been given approximately 3 days previously.

\section{Discussion}

A success rate of 95.4 per cent. in this highly selected group of cases containing a large proportion of infections by gonococci partially resistant to penicillin seems very satisfactory. Side-effects from kanamycin, such as ototoxicity and renal toxicity, were not encountered and it is generally understood that they do not occur at these doses in subjcets with normal renal function.

\section{Summary}

Kanamycin sulphate $2 \mathrm{~g}$. intramuscularly was used in the treatment of 100 cases of gonorrhoea selected on the basis of failure of treatment with 800,000 units fortified procaine penicillin. In 83 cases the strains were shown to be partially resistant to penicillin by in vitro tests. 87 patients could be assessed and failure of treatment occurred in two of 37 cases in women and two of fifty cases in men, an overall success rate of 95.4 per cent.

There were minor side-effects of the treatment in only six cases, but not all were necessarily due to the drug.

I should like to thank Dr. Rosemary Simon for the bacteriological work involved in this paper; Miss Keefe and her staff for her work with the records; and Dr. R. D. Catterall for his help and guidance. Kanamycin sulphate (Kantrex) was supplied by courtesy of Dr. B. M. Barker of Bristol Laboratories Ltd.

TABLE II

RESULTS OF TREATMENT AND EXTENT OF FOLLOW-UP IN MALES WITH URETHRITIS

\begin{tabular}{|c|c|c|c|c|c|c|}
\hline \multirow{2}{*}{$\begin{array}{l}\text { Total } \\
\text { No. of Cases }\end{array}$} & \multicolumn{3}{|c|}{ Immediate Treatment } & \multicolumn{3}{|c|}{ Follow-up (length) } \\
\hline & Default & Failure & Success & 1 week & 1 month & 3 months \\
\hline 51 & 13 & 2 & 36 & 4 & 20 & 12 \\
\hline
\end{tabular}

TABLE III

RESULTS OF TREATMENT AND EXTENT OF FOLLOW-UP IN FEMALE CASES AND IN MALES WITH PROCTITIS

\begin{tabular}{|c|c|c|c|c|c|c|c|c|}
\hline \multirow{2}{*}{ Sex } & \multirow{2}{*}{$\begin{array}{c}\text { Total } \\
\text { No. of } \\
\text { Cases }\end{array}$} & \multirow{2}{*}{$\begin{array}{c}\text { Immediate } \\
\text { Default }\end{array}$} & \multicolumn{2}{|c|}{ Treatment } & \multicolumn{4}{|c|}{ Follow-up (No. of negative smears and cultures) } \\
\hline & & & Failure & Success & 1 & 2 & 3 & More than 3 \\
\hline Females & 37 & Nil & 2 & 35 & 4 & 14 & 5 & 12 \\
\hline Male with Proctitis & 12 & $\mathrm{Nil}$ & Nil & 12 & 1 & 5 & 6 & Nil \\
\hline
\end{tabular}




\section{REFERENCES}

Hooton, W. F., and Nicol, C. S. (1967). Postgrad. med. F., 43, May Supplement, p. 68.

WILkINSON, A. E., RACE, J. W., and CuRTIS, F. R. (1967), Ibid., 43, May Supplement, p. 65.

Le sulfate de kanamycine dans le traitement des gonococcies ne répondant pas à la pénicilline

\section{RÉsumé}

Le sulfate de kanamycine, à la dose de $2 \mathrm{~g}$. par voie intramusculaire, fut utilisé pour le traitement de 100 cas de gonococcie choisis du fait de l'échec d'un traitement par 800.000 unités de pénicilline-procaïne renforcée. Dans 83 cas, les souches se montraient partiellement résistantes in vitro à la pénicilline. 87 cas purent être évalués et le traitement échoua dans 2 des 37 cas féminins et dans 2 des $\mathbf{5 0}$ cas masculins, soit un pourcentage total de succès de 95,4.

On observa des effets secondaires mineurs du traitement dans six cas seulement mais qui n'étaient pas tous dus nécessairement au médicament. 